\title{
A Study on Awareness Levels and Adaptation Strategies for Climate Variability among Farmers
}

\author{
Dr. Ch. Srilatha Vani, Dr. P. B. Pradeep kumar \\ ${ }^{1}$ Scientist (Extension), RARS, Anakapalle,Angrau, Guntur, A.P, India \\ ${ }^{2}$ Scientist, DAATTC, Visakhapatnam, Angrau, Guntur, A.P, India
}

\begin{abstract}
Climate change has become a severe threat to the development and communities around the globe are already experiencing the sudden impacts. It is also being assumed that climate change will have significant negative impacts on agricultural productivity. In this respect 120 farmers were interviewed as respondents to explore the climate variability/change awareness and farmers mitigation strategies. This study was conducted in Rangareddy district of Telangana.Three mandals were selected randomly. From each mandal two villages and from each village 20 farmers were selected randomly.Total number of respondents are 120 Findings of the study indicated that farmers' awareness regarding climate variability was very poor they were just having knowledge on behalf of their farming experience. Varied response was seen regarding causes of climate change. In addition, adaptations of mitigation strategies such as natural resource management, water harvesting, crop diversification migration to less weather prone area and usage of weather resistant varieties were almost negligible. Results showed that out of 15 adaptation strategies, micro irrigation ranked first among farm adaptive measures, while crop insurance has ranked as least utilized. Conservation agriculture could be the most viable strategy. Farmers have to utilize their existing resources in judicious ways. It is suggested on the basis of findings that role of extension field staff should be diversified. Farmers need capacity building regarding conservation agriculture. Moreover, it is dire need to popularize climate change and its adaptation through effective media campaign.
\end{abstract}

Keywords- Conservation agriculture, Crop insurance, capacity building.

\section{INTRODUCTION}

Climate change constitutes a very serious threat to sustainable agricultural production and food security in many parts of the world. Climate change impacts on agriculture include biological effect on crop yield, the resulting impact on prices, production, consumption and the impact on per capital calorie consumption and malnutrition. Research findings have shown that agriculture in developing countries is currently being affected by climate change. Unless appropriate mitigation and adaptation measures are taken, climate change will frustrate farmers' efforts to achieve sustainable agricultural production and food security. However, developing such strategies will require information from the farmers since the ability to adapt and cope with climate change depends on their awareness on different aspects. It is against this background that this study seeks to assess the awareness of the farmers on climate change, and to identify the farmers' response and adaptation to the problem.

\section{METHODOLOGY}

This study was conducted in Rangareddy district of Telangana .Three mandals were selected randomly .From each mandal two villages and from each village 20 farmers were selected randomly. Total number of respondents are 120 .This study is principally based on the primary data obtained from the farmers using a structured schedule .Information regarding awareness levels of farmers towards the adverse effect of climate change, perceived causes/reasons for climate change and mitigation strategies fallowed by farmers. Interview schedule was used as research tool, which was prepared keeping in mind the all set objectives of the research. The interview schedule was pre-tested before final data collection. The reliability and validity of research instrument was also checked. Further, respondents were personally interviewed for the accurate acquisition of data. Collected data were analyzed through computer software Statistical Package for Social Sciences (SPSS) for tabulating results and drawing conclusions and recommendations. Average mean and standard deviation were also computed for the better understanding. 


\section{RESULTS AND DISCUSSION}

Table .1: Distribution of respondents according to their Awareness levels

$(n=120)$

\begin{tabular}{|l|l|l|l|}
\hline $\begin{array}{l}\text { S. } \\
\text { No }\end{array}$ & Category & $\begin{array}{l}\text { Frequenc } \\
\mathbf{y}\end{array}$ & Percentage \\
\hline 1. & Aware & 80 & 66.7 \\
\hline 2. & Not aware & 40 & 33.3 \\
\hline
\end{tabular}

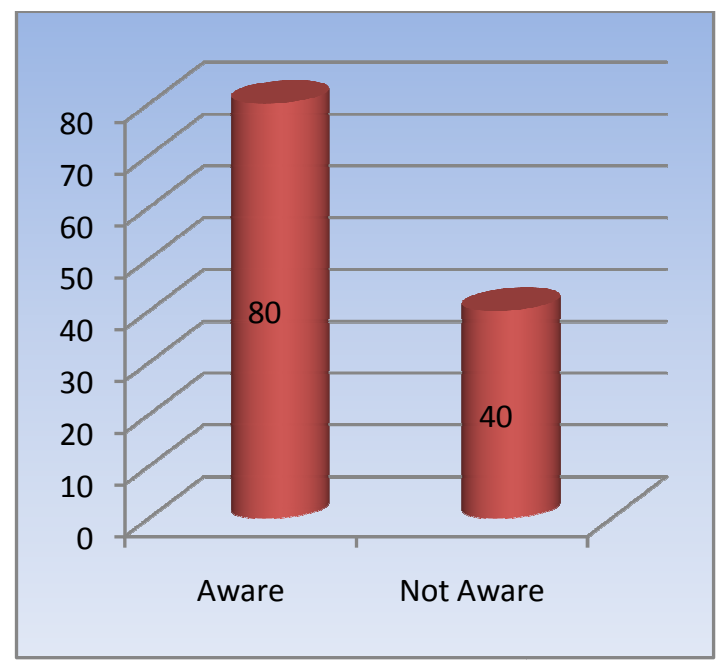

Fig. 1: Distribution of respondents according to their Awareness levels

\section{Climate Change Awareness}

When asked whether they were aware of climate change and its impacts on both their agricultural production and livelihoods in general, majority of the respondents $(66.7 \%)$ said yes (fig.1). This is an indication that climate change has indeed moved from being a hypothesis to being a reality. More than half of them $(60 \%)$ pointed out that media contributed to their awareness of climate change and its impacts. However, $25 \%$ of the responding farmers claim that their awareness is because of university extension. It must be noted that the highest education level of respondents is high school and that their understanding of climate change is limited to their daily experiences and information from radio broadcast, hence, the need that media outreach through radio is enhanced so that more farmers can be reached and informed about climate change, its causes, consequences, mitigation and adaptive measures. When asked what they think should be done to spread climate change awareness, participants pointed out that both workshops and public gatherings can be organized to share information and knowledge between farmers and researchers (through extension services).

Table .2: Awareness of farmers towards causes/factors effecting Climate change

\begin{tabular}{|l|l|l|l|}
\hline \multicolumn{2}{|l}{$\begin{array}{l}\text { S. } \\
\text { No }\end{array}$} & Causes of climate change & \multicolumn{2}{|c|}{ Yes } \\
\cline { 2 - 4 } & F & $\%$ \\
\hline 1. & $\begin{array}{l}\text { Domestic activities (i.e. Ac \& } \\
\text { refrigerators, oven and automobile } \\
\text { plants) }\end{array}$ & 30 & 25.0 \\
\hline 2. & Deforestation & 39 & 32.5 \\
\hline 3. & Emission of green house gasses & 2 & 1.67 \\
\hline 4. & Land use changes & 0 & 0 \\
\hline 5. & Carbon sequestration in soils & 0 & 0 \\
\hline 6. & Industrial activities & 5 & 4.2 \\
\hline & Natural process destined by God & 4 & 3.3 \\
\hline 7. & Don't know about the reasons & 43 & 35.8 \\
\hline
\end{tabular}

The awareness of the respondents as to the causes of climate change (Table 2) shows that nearly $35.8 \%$ of the respondents don't know the reasons for climate change .about $32.5 \%$ perceived climate change as being caused by deforestation, bush burning, and overgrazing by livestock. This was followed by Domestic activities (i.e. Ac \& refrigerators, oven and automobile plants) natural process destined by God, as claimed by $3.3 \%$ of the respondents, while $4.2 \%$ ) of the respondents claimed that industrial activities are responsible for climate change. Other causes of climate change are Natural process destined by $\operatorname{God}(3.3 \%)$ and emission of green house gases(1.67\%).they don't have any knowledge of Land use changes and Carbon sequestration in soils. 


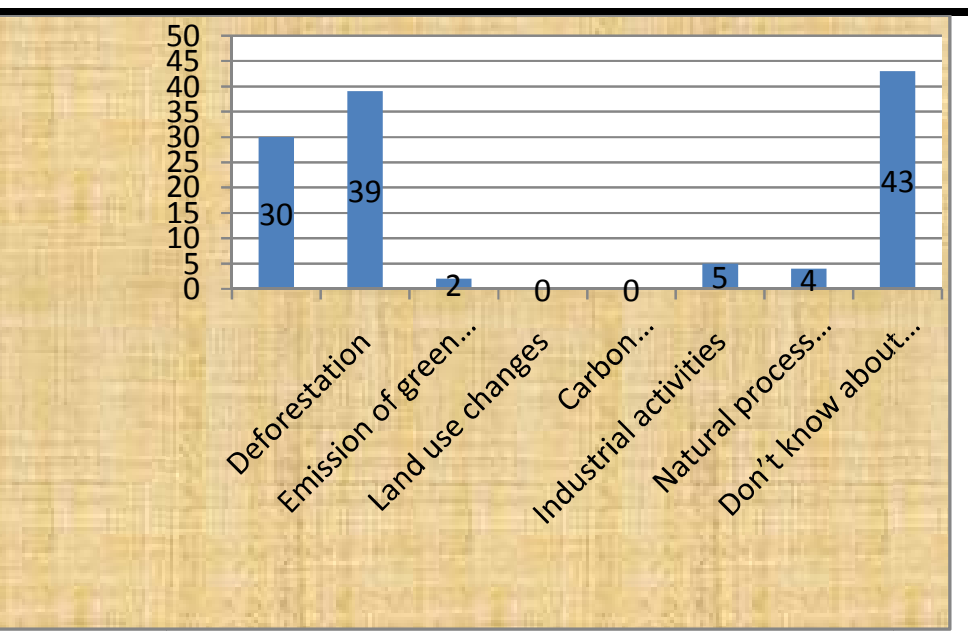

Fig.2: Awareness of farmers towards causes/factors effecting Climate change

Table .3: Awareness of farmers towards effect of Climate change on farming

$(n=120)$

\begin{tabular}{|l|l|l|l|l|l|}
\hline \multirow{2}{*}{ S. No } & \multirow{2}{*}{ Effect of climate change } & \multicolumn{2}{|c|}{ Response } \\
\cline { 3 - 6 } & & \multicolumn{2}{|c|}{ Yes } & \multicolumn{2}{c|}{ No } \\
\cline { 3 - 6 } & & F & \% & F & \% \\
\hline 1. & Reduced yield & 80 & 66.7 & 40 & 33.3 \\
\hline 2. & Pest and Disease outbreak & 50 & 41.7 & 70 & 58.3 \\
\hline 3. & Raise of soil temperature \&Fast evaporation of soil moisture & 20 & 16.7 & 100 & 83.3 \\
\hline 4. & Erratic rainfall & 75 & 62.5 & 45 & 37.5 \\
\hline 5. & Crop failure & 60 & 50.0 & 60 & 50.0 \\
\hline 6. & Shifting of Seasons & 55 & 45.8 & 65 & 54.2 \\
\hline 7. & Decline in soil fertility & 45 & 37.5 & 75 & 62.5 \\
\hline
\end{tabular}

In order to know the comparative perception of the farmers on 7 selected aspects cumulative frequency and percentages were calculated. According to them majority of the farmers $(66.7 \%)$ perceived that reduced yield is the effect of climate change fallowed by erractic rainfall $(62.5 \%)$ and crop failure (50.0\%).very low percentage (16.7 \%) of people perceived Raise of soil temperature \&Fast evaporation of soil moisture as an effect of climate change .

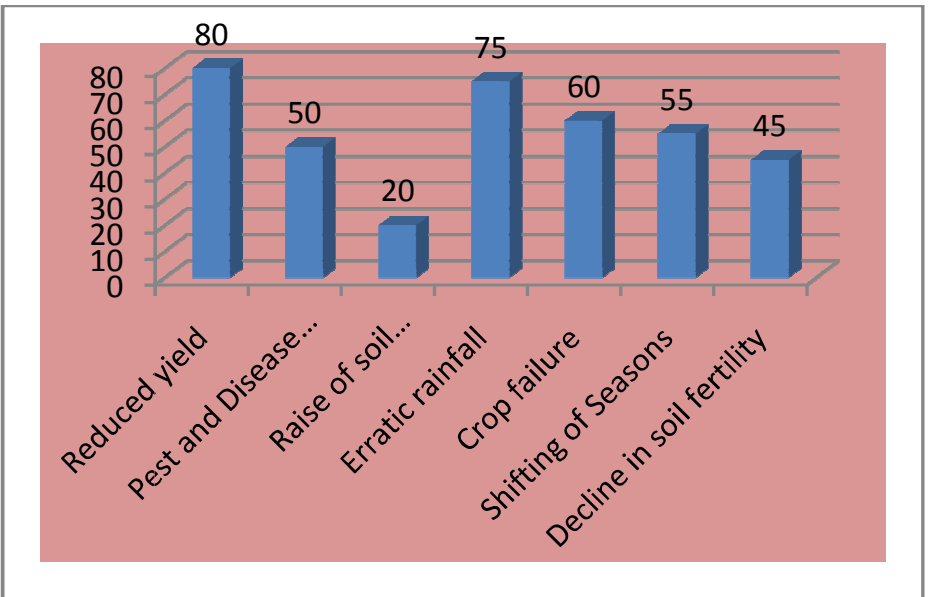

Fig.3: Awareness of farmers towards effect of Climate change on farming 
Table. 4: Source of awareness about climate change

$(n=120)$

\begin{tabular}{|l|l|l|l|}
\hline S.No & Source & Frequency & Percentage \\
\hline 1 & Agriculture Department & 10 & 8.33 \\
\hline 2 & University scientists & 30 & 25.0 \\
\hline 3 & Media & 72 & 60.0 \\
\hline 4 & NGOs & 5 & 41.7 \\
\hline 5 & Friends and neighbours & 3 & 25.0 \\
\hline
\end{tabular}

Media is the main source of transfer of technical information among farmers. University extension centres placed in second position. If the extension agents are empowered with knowledge/information about climate change, there is high likelihood that such information may reach local farmers.

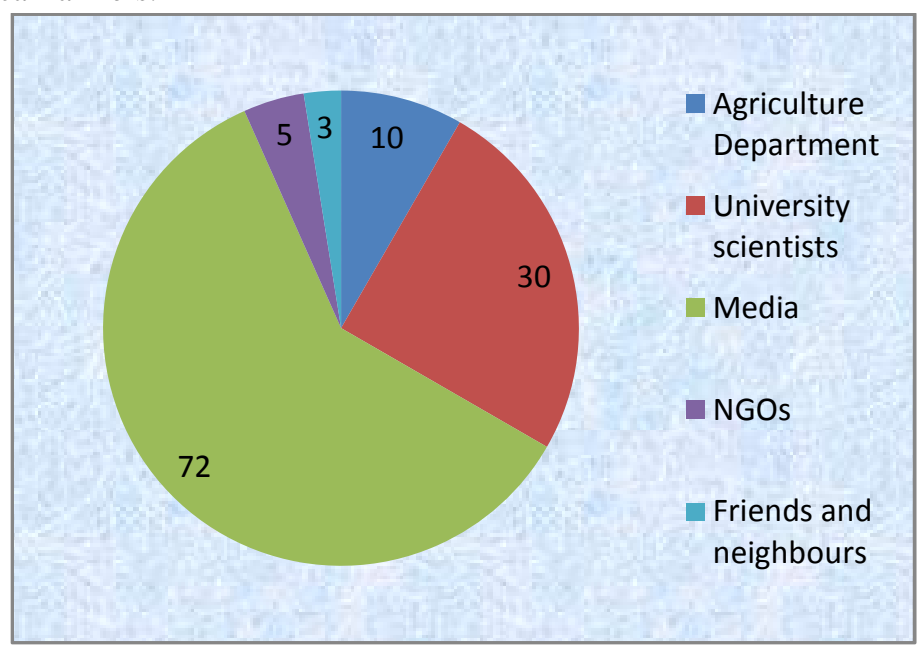

Fig.4: Source of awareness about climate change

Table.5: Adaptation measures adopted by farmers to mitigate climate variability/change

\begin{tabular}{|l|l|r|l|}
\hline \multirow{2}{*}{ S.No } & Technology & \multicolumn{2}{l|}{ Adoption behaviour \% } \\
\cline { 3 - 4 } & & 44.2 & \multicolumn{2}{l|}{ Adopted } & Not Adopted \\
\hline 1. & Conversion/reduced tillage agriculture & 34.0 & 66.0 \\
\hline 2. & Increased intensity of land use & 45.8 & 54.2 \\
\hline 3. & Optimum utilization of Agricultural chemicals & 20.0 & 80.0 \\
\hline 4. & Better capture and storage of rain water & 31.8 & 68.2 \\
\hline 5. & Revising planting dates ,plant densities and crop sequence & 69.2 & 30.8 \\
\hline 6. & Use of organics /green manuring in sequence cropping & 22.0 & 88.0 \\
\hline 7. & Micro irrigation & 32.2 & 67.8 \\
\hline 8. & Integrated natural resource management & 27.0 & 73.0 \\
\hline 9. & Use of Resistant varieties & 22.8 & 77.2 \\
\hline 10. & Change in cropping patterns & & \\
\hline
\end{tabular}




\begin{tabular}{|l|l|l|l|l|}
\hline 11. & Crop diversification & 31.7 & 68.3 \\
\cline { 2 - 5 } & 12. & Crop rotation & 54.4 & 45.6 \\
\hline 13. & Practices to promote natural enemies & 21.0 & 79.0 \\
\hline 14. & Crop insurance & 11.0 & 89.0 \\
\hline
\end{tabular}

The result of adaptation measures responded by the respondents against climate change (Table 5) shows that majority $(69.2 \%)$ of the respondents is using organics /green managing in sequence cropping. Crop rotation was also practiced by $54.4 \%$ of the respondents to pest incidence. About $45.8 \%$ of the respondents reported they are following optimum utilization of Agricultural chemicals. Other adaptation measures used by the respondents include use of resistant varieties ,crop rotation, Revising planting dates ,plant densities and crop sequence, reduced tillage, change in cropping pattern, rain water storage etc.

\section{CONCLUSION}

The study proved high level of awareness of farming community in the study area. About 66.7 per cent respondents knew about climate change in the area, while few respondents had awareness about the causes of climate change. The findings suggest that awareness among the respondents was mainly due to media fallowed by university scientists. So, it is of immediate importance to introduce climate change education among the farmers through extension functionaries of different organizations at different level. The formulated extension strategies need to be incorporated as the guideline in future climate resilient extension strategies for sustainable agricultural development. Extension must help farmers prepare for greater climate variability and uncertainty, create contingency measures to deal with exponentially increasing risk and alleviate the consequences of climate change by providing advice on how to deal with droughts, floods and so forth. Poor resource farmers have to be trained more for they are less enlightened mostly illiterate and neglected from the mainstream of development.

\section{REFERENCES}

[1] Akanda and Howlader ,M.S.2015. Coastal Farmers'Perception of Climate Change Effects on Agriculture at Galachipa Upazila under Patuakhali District of Bangladesh. Global Journal of Science Frontier Research: D Agriculture and Veterinary .Volume 15 Issue 4 Version1.0

[2] Harshal, T.Pandve. (2011). Assessment of awareness regarding climate change in an urban community. Indian J Occup Environ Med.; 15(3): 109-112
[3] IFPRI .2009. Climate Change: Impact on agriculture and costs of adaptation. International Food Policy Research Institute, Washington, D

[4] Maharjan ,S.K; Sidgel E.R; Sthapit B.R. \& Regmi B.R 2011.Tharu community's perception on climate change and their adaptive initiations to withstand its impacts in Western Terai of Nepal. International NGO Journal vol. 6(2) pp 35-42.

[5] Mohammed Nasir Uddin.2014.Factors Affecting Farmers'Adaptation Strategies to Environmental Degradation and Climate Change Effects:A Farm Level Study in Bangladesh. Climate. 2, 223-241

[6] Rakib , M.A .2014. Climate change: farmers perception and agricultural activities. Herald Journal of Geography and Regional Planning Vol. 3 (3): 115123

[7] Sekaleli T.S.T and Sebusi.K. African Technology Policy Studies, ATPS 2013: Farmers' Response and their Adaptation Strategies to Climate Change in Mafeteng District, Research Paper No. 26

[8] Sujit Sarkar and Padaria.r.N.2015. Measuring Farmers' Awareness and Knowledge Level about Climate Change and Formulating Future Extension Strategies. Indian Res. J. Ext. Edu. 15 (1), January, 2015,pp:107-111

[9] Adebayo A.A and Onu J.I.2012 . Farmers' Awareness, Vulnerability and Adaptation to Climate Change in Adamawa State, Nigeria. British Journal of Arts and Social Sciences ISSN: 2046-9578, Vol.9 No.II CBritishJournal Publishing, Inc. 2012 http://www.bjournal.co.uk/BJASS.aspx.pp: 104-115 